\title{
10 年間の皮膚悪性新生物
}

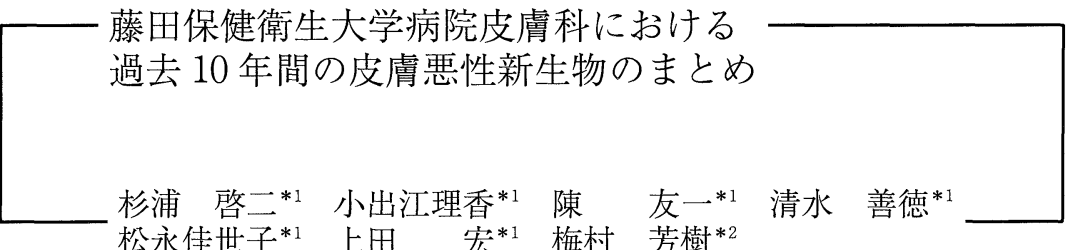
松永佳世子 ${ }^{* 1}$ 上田 宏*1 梅村 芳樹

\section{Summary}

We reported a total of 229 cases of malignant skin tumors that were pathologically diagnosed at the Department of Dermatology, Fujita Health University Hospital between January 1989 and June 1998. The incidence of malignant skin tumors was $0.73 \%$ of 31,379 new patients during the period. The male versus female ratio was $1.17: 1$. The commonest malignant skin tumors were squamous cell carcinomas (SCC) and which showed an increasing trend. The basal cell carcinomas (BCC) versus SCC ratio were 0.91, which resembled that of western Japan. We experienced 8 angiosarcomas. Among them 3 are alive during this period. They are all male patients who have been treated with interleukin 2 .

Key words : Malignant skin tumors, Statistical study

\section{はじめに}

本邦での皮膚悪性新生物の発生率は欧米人に 比し少ないが，近年高齢化社会にともない増加 傾向にある ${ }^{1) 21}$ 。今回, 当科においてもその発生 率の推移を検討するため, 過去 10 年間に病理組 織学的に診断し得た皮膚悪性新生物についてま とめ，興味ある結果を得たので，文献的考察を 加え検討した。

対 象：対象は 1989 年 1 月より 1998 年 6 月 までに当科を受診した男性 17,258名，女性 14,121 名のうち病理組織学的に皮膚悪性新生物 と診断した 11 歳〜 94 歳（平均 65.2 歳）の 229

*1 Keiji SUGIURA, Erika KOIDE, Yuichi CHIN, Yoshinori SHIMIZU, Kayoko MATSUNAGA, Hiroshi UEDA：藤田保健衛生大学病院皮膚科

*2 Yoshiki UMEMURA : 新城市民病院皮膚科
例。対象疾患は表皮系が基底細胞癌 (BCC), 扁 平上皮癌 (SCC)，色素細胞系が悪性黒色腫 $(\mathrm{MM})$, 乳房外パジェット病 (Em Paget 病), 間 葉系が悪性線維性組織球腫 $(\mathrm{MFH})$ ，血管肉腫 (Angiosarcoma)，網内系が成人 $\mathrm{T}$ 細胞白血病 (ATL)，急性リンパ性白血病 (ALL)，急性骨髄 性白血病 (AML), 慢性リンパ性白血病 (CLL), 慢性骨髄性白血病 (CML), 菌状息肉症 $(\mathrm{MF})$, 悪性リンパ腫（ML)，転移性皮膚腫瘍を対象と L，Bowen 病，日光角化症は除いた。なお 1 個 人に異なった腫瘍を認めた場合 2 種とした。

\section{結＼cjkstart果}

1. 頻度

1) 男女比

229 例のうち男性 124 名 (54\%)，女性 105 名 (46\%) で男性に多く認めた。男女比は 1.17:1で 
あった。疾患別では表皮系，色素細胞系，間葉 系，網内系で男性に多く認められ, Em Paget 病 は女性に多く，転移性皮膚腫瘍は男女同数で あった。

\section{2 ) 年齢別症例数}

年齢別腫瘍数では 60 歳代， 70 歳代の高齢者 に多く認められた（図 1 )。最小年齢は 11 歳の CTCL で，最高年齢は 94 歳の SCC であった。

\section{3 ) 総新患患者に対する頻度}

過去 10 年間の総新患患者数に対する皮膚悪 性新生物の比率を検討したところ $0.73 \%$ を占 め，前期 5 年間と後期 5 年間を比較したところ 症例数だけでなく，総新患患者数に対する比率 も $0.53 \%$ から $0.96 \%$ と後期 5 年間に増加傾向を 認めた（図 2 )。

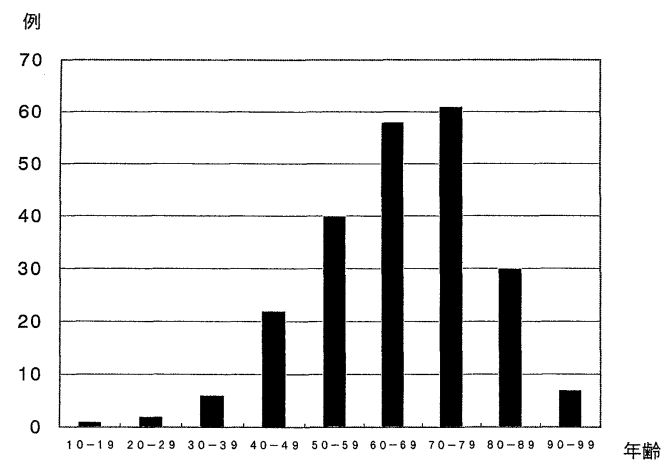

図 1 . 過去 10 年間の年齢別腫瘍数

\section{4 ）疾患別頻度}

過去 10 年間の疾患別頻度では SCC が最も多 かった（図 3）。また過去 10 年間の総新患患者 数に対する各腫瘍別の比率で，前期 5 年間と後 期 5 年間で比較したところ明らかに比率の上昇 を認めるのは SCC であった（図 4 ）。

\section{2. 表皮系腫瘍}

\section{1) $\mathrm{SCC}$}

SCC の年齢別性差をみると男性では 70 歳代 にピークがあるが，女性では加齢とともに SCC の数の増加を認め, 80 歳代にピークがあった (図 5 )。部位については顔面が多く，露光部は 約 $80 \%$ を占めた。

\section{2) BCC}

BCC の年齢別性差では大差なく, 男女ともに

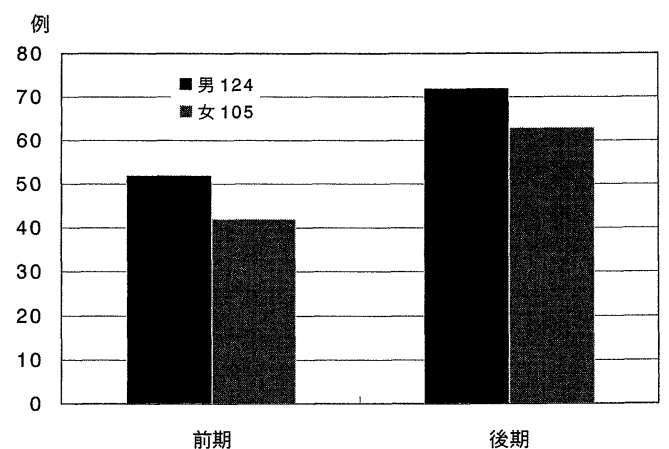

図 2. 過去 10 年間の男女別前後期別症例数

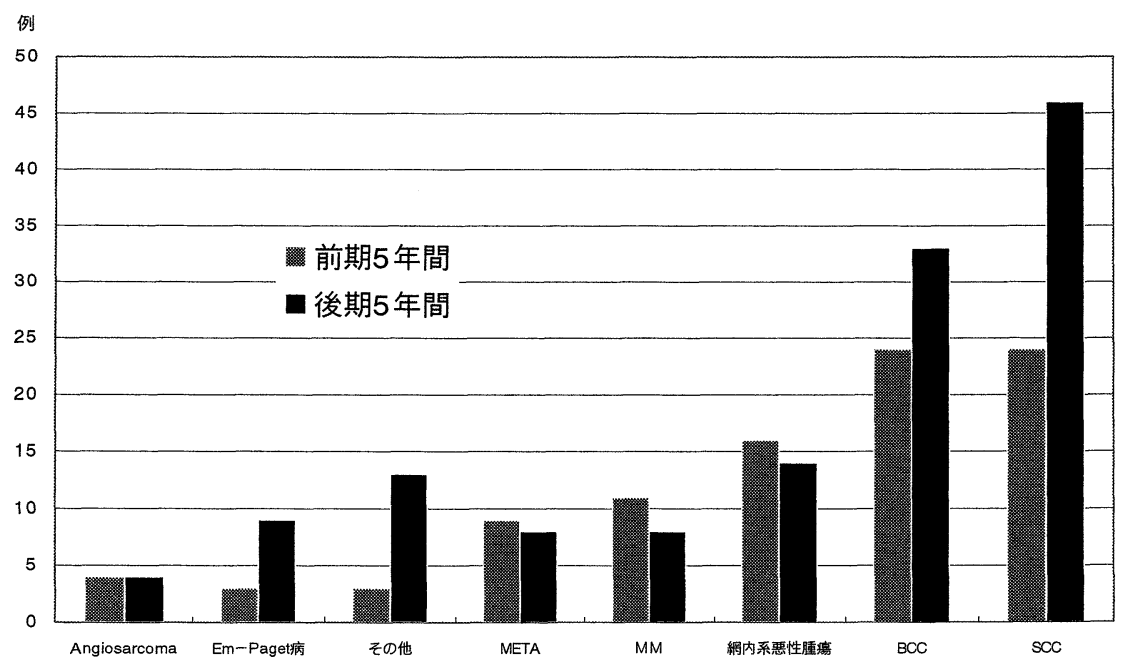

図 3．過去 10 年間の前後期別腫瘍数 


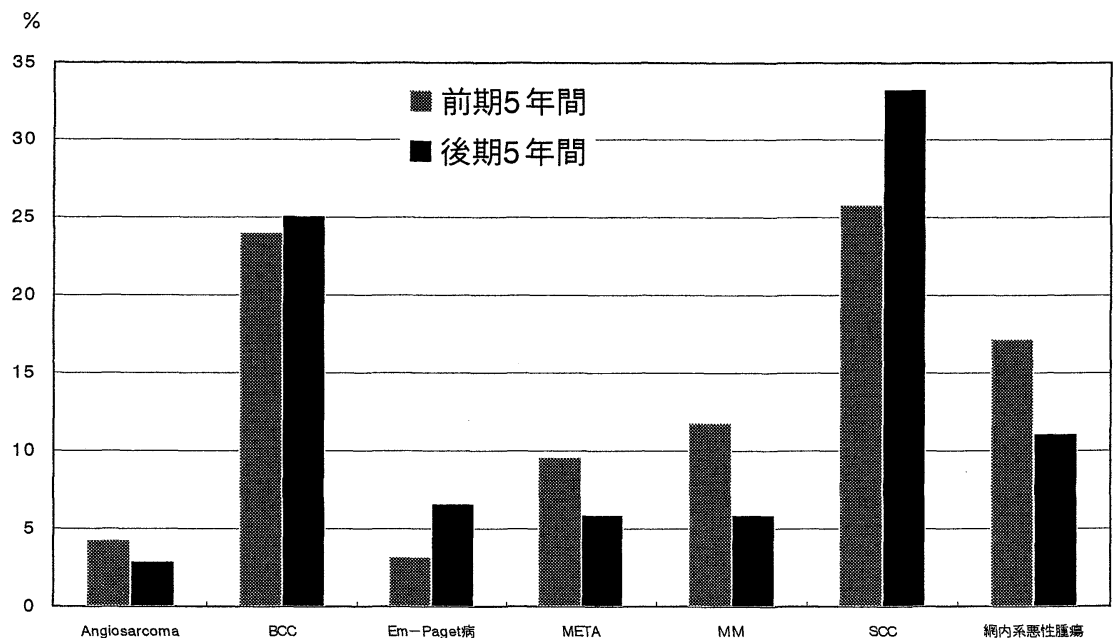

図 4. 過去 10 年間の総新患患者に対する各疾患別の前後期別比率

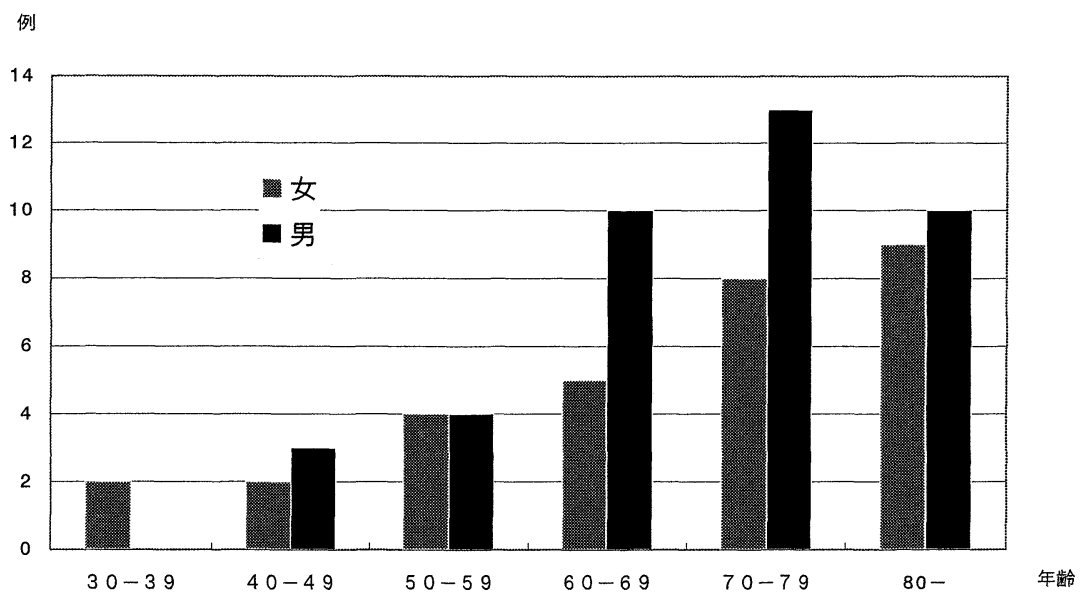

図 5. 過去 10 年間の SCC の年齢別症例数

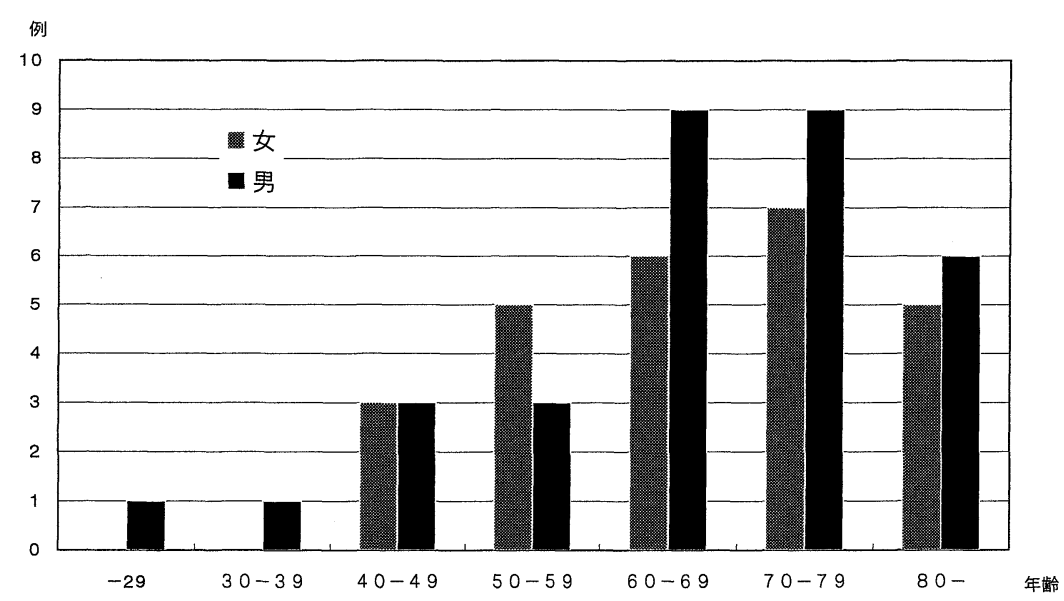

図 6. 過去 10 年間の BCC の年齢別症例数 
平均年齢は 67 歳であった（図 6 )。部位につい て顔面が $75.5 \%$ と最も多かった。

\section{3 ) $\mathrm{BCC} / \mathrm{SCC}$ ratio}

BCC/SCC ratio は 0.91 であった。

\section{3. 色素細胞系腫瘍 (表 1 )}

$\mathrm{MM}$ は過去 10 年間で 19 例あり男女比では男 性に多く, 平均年齢は男女ともに 59.7 歳と他の 疾患より若かった。またUICC の TNM 分類に よる stage 分類では stage I が7例と最も多かっ た。また発生部位では足底が 6 例と最も多かっ た。

\section{Em Paget 病}

Em Paget 病は過去 10 年間に 12 例あり男女比 は $1: 1.4$ と女性に多く，また 12 例のうち 1 例は double Paget 病 (外陰, 腋) で,ささらに稀な 1 例として著者らが報告 ${ }^{4)}$ している腎移植後の Em Paget 病も経験した。

\section{5. 間葉系腫瘍（表 2）}

Angiosarcoma は過去 10 年間で 8 例と比較的 多数の症例があり，全ての症例が 60 歳以上で あった。臨床病型では結節型が多く，部位では 頭部が最多であった。生存例については全て男 性で, interleukin 2 (IL-2) を使用しており，う ち斑状型の 1 例は IL-2 動注例で他 2 例は結節型 で局注例であった。また $\mathrm{MFH}$ は 10 年間で 3 例 経験し，現在全て生存している。また比較的稀 な部位として左煩部の症例があった。

\section{6. 網内系腫瘍}

疾患別では, ATL が 8 例で最も多く, 男女比 では 1.38:1 で男性に多かった。年齢では CTCL の 11 歳の症例が最年少であった。

\section{7、転移性皮膚腫瘍}

原発組織では肺癌が最も多く, 次いで乳癌を 多く認めた。肺癌の組織型では 3 例が腺癌で 2 例が扁平上皮癌であった。

表 1 ．過去 10 年間の $\mathrm{MM}$ の症例一覧

\begin{tabular}{|c|c|c|c|c|}
\hline 期 & 年 齢 & 性 別 & 生 存 期 間 & 転 帰 \\
\hline & 60 & 男 & 不明 & 不明 \\
\hline \multirow[t]{6}{*}{1} & 63 & 男 & 不明 & 不明 \\
\hline & 48 & 男 & 2年2ヶ月 & 生存 \\
\hline & 42 & 男 & 3年7ヶ月 & 生存 \\
\hline & 58 & 女 & 7年3ヶ月 & 生存 \\
\hline & 58 & 男 & 7年8ヶ月 & 生存 \\
\hline & 64 & 女 & 10年 & 生存 \\
\hline \multirow[t]{5}{*}{2} & 63 & 男 & 不明 & 不明 \\
\hline & 71 & 女 & 10ヶ月 & 死亡 \\
\hline & 61 & 女 & 4年1ヶ月 & 死亡 \\
\hline & 63 & 男 & 4年8ヶ月 & 生存 \\
\hline & 55 & 男 & 7年6ヶ月 & 生存 \\
\hline \multirow[t]{5}{*}{3} & 64 & 男 & 5ヶ月 & 生存 \\
\hline & 54 & 女 & 1年1ヶ月 & 生存 \\
\hline & 52 & 男 & 1 年5ヶ月 & 生存 \\
\hline & 47 & 女 & 1年10ヶ月 & 死亡 \\
\hline & 75 & 男 & 3年 & 生存 \\
\hline 4 & 60 & 女 & 1 年 6 ヶ月 & 死亡 \\
\hline
\end{tabular}

表 2. 過去 10 年間の Angiosarcoma の一覧

\begin{tabular}{|c|c|c|c|c|c|c|}
\hline 年齢 & 性別 & 部位 & 臨床病型 & 治療 & 生存期間 & 予後 \\
\hline $60^{*}$ & 女 & 右鼠径 & 結節型 & 手術 & 不明 & 死亡 \\
\hline 71 & 女 & 右撤部 & 結節型 & 手術、化学療法 & Зヶ月 & 死亡 \\
\hline 64 & 男 & 下腿 & 斑状型 & $\mathrm{IL}-2$ & 4 ヶ月 & 死亡 \\
\hline 62 & 男 & 左頬部 & 斑状型 & 手術、化学療法、IL-2、電子線 & 2 年 & 死亡 \\
\hline 75 & 女 & 頭部 & 結節型 & IL-2、電子線 & 3年 & 死亡 \\
\hline 69 & 男 & 頭部 & 結節型 & 手術、IL-2、電子線 & Зヶ月 & 生存 \\
\hline 71 & 男 & 頭部 & 斑状型 & 手術、IL-2、電子線 & 2 年 & 生存 \\
\hline 72 & 男 & 頭部 & 結節型 & IL-2、電子線 & 3年 & 生存 \\
\hline
\end{tabular}

*Stewart-Treves症候群 


\section{考案}

当科 10 年間で経験した皮膚悪性新生物 229 例 につき報告した。男女比では男性 124 例，女性 105 例（男：女 $=1.17: 1$ ） と顕著な差はなく, 九州大 ${ }^{5)}$ ，山口大 ${ }^{6)}$ の報告と同様に明らかな男 女差は認められていない。外来総新患患者に対 する皮虐悪性新生物の割合は $0.73 \% て ゙ ，$ 他施設

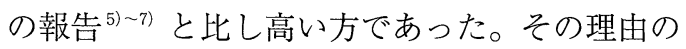
1 つは大学病院であり悪性新生物患者の受診が 多いためと思われる。また前期，後期 5 力年の 比較では後期 5 年間の方が腫瘍数, 総新患患者 に対する比率も増加しており，その原因として 老齢者人口の増加, 医療医学の普及, 皮膚疾患 に対する認識の向上, 生活習慣の欧米化などが 挙げられる。

\section{1. 表皮系腫瘍}

菊池ら ${ }^{7)}$, 上田ら ${ }^{8)}$, Tada $5^{9)}$ の報告と異な り，BCC を抜き SCCが当科では最も多かった。 この点について明らかな原因は不明だが，SCC の患者の職業に農業, 建設業が多い傾向があ り, 紫外線暴露時間が長くそれによるActinic keratosis が基礎にあるためと思われる。BCC, $\mathrm{SCC}$ の年齢構成として, BCC では当科清水ら ${ }^{10)}$ が報告している 19 歳の基礎疾患のない稀な症 例が最小年齢であった。SCCではとくに女性に おいて年齢を経るごとにその数が増加し 80 歳 代がピークで, 男性では70歳代がピークでその 後減少している。このことは女性の寿命が男性 よりも長いことが起因していると思われた。村 山ら ${ }^{3)}$ が報告している BCC/SCC ratio は人種 差，地域差があるといわれているが，当科では 10 年間の平均が 0.91 と西日本のものと近似し ていた。これは当科ではSCCが多いためと考え られる。

\section{2. 色素細胞系腫瘍}

発症年齢は 60 歳以降に, 発症部位では足底に

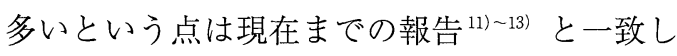
ている。生存期間についてはstage I， II は stage III，IVよりも長い傾向があるが，この点に ついてはさらに症例を積み重ねていく必要があ る。なお，今回の統計には入っていないが，当 科で経験した最長生存期間の MM は 12 年生存 した女性例であった。

\section{Em Paget 病}

当科での男女比は $1: 1.4$ と女性に多く, これ までの報告 ${ }^{14)}{ }^{15)}$ とは異なっていた。これは症例 数が少ないことも起因していると考えられるの で，さらに症例を積み重ねる必要がある。

\section{4. 間葉系腫瘍}

Angiosarcoma の IL-2 使用例は 8 例中 6 例で あった。最長生存期間は 36 カ月で平均生存期間 は21 カ月であった。IL-2, 電子線併用例は IL2 単独使用例, IL-2 不使用例よりも生存期間が 長い傾向があり，併用した方が治療効果が高い 可能性がある。

\section{5. 網内系腫瘍}

今回の検討では男女共に平均年齢が 50 歳代 と比較的若い結果を得た。これは当院が大学病 院であり血液化学療法科があるためと思われ る。

\section{6．転移性皮膚腫瘍}

転移性皮膚腫瘍は原発巣の進行した状態であ ることがほとんどで, その頻度は皮膚癌性腫瘍 の約 6\%といわれている ${ }^{16)}$ 。Brownstein \& Helwig ${ }^{17)}$ による分類では結節型が 11 例と最も 多かった。

本邦では乳癌 $>$ 胃癌 $>$ 肺癌の順に多いといわ れているが, 我々の統計では肺癌が多く胃癌は 認めなかった。肺癌が多いことに関しては近年 の肺癌の増加が影響しているものと思われる。 年齢では女性が57.8歳, 男性が 65 歳とほぼ癌年 齢に一致していた。女性が若いことは福井 $ら^{18)}$, 龍崎ら ${ }^{19)}$ の報告と同様で, これは乳癌の 症例が多いこと, そして乳癌の発症年齢が他の 疾患より若いことがあげられる。また発症部位 で胸部が多いのは原発巣の被覆部位であり，ま た頭部, 顔面に多いのは血流が豊富なためと考 えられた。 
最後に, 以上当科における過去 10 年間の皮膚 悪性新生物のまとめを報告したが，今後さらに 症例を増やし，各々の疾患について検討してい きたい。

\section{文献}

1）梅田整, 飯田秀夫, 青木一浩, 他: 東京医科歯科 大学皮膚科における過去 6 年間の皮虐悪性腫瘍の 統計. Skin Cancer, 8: 126-130, 1993.

2) 高橋泰英: 横浜市立大学医学部皮膚科における上 皮系悪性腫瘍の統計的観察. Skin Cancer, 6:460467, 1991.

3）村上功子, 阿部澄乃, 吉池高志, 他: 順天堂大学 浦安病院に抢ける過去 10 年間の皮虐悪性腫瘍の 統計. Skin Cancer, 12 : 96-103, 1997.

4）杉浦啓二, 陳友一, 鈴木加余子, 他：腎移植後に 生じた乳房外 Paget 病の 1 例. 皮虐, $40: 379-383$, 1998.

5）今山修平, 永江祥之介：九大皮膚科 75 年間の悪性 腫瘍の統計。西日皮膚，43:974-983, 1981.

6) 山口康則, 麻上千鳥, 浪花志郎, 他 : 最近 20 年 間における皮虐悪性腫瘍教室例の検討。西日皮 膚，46（増）：107-109, 1984.

7）菊池新, 清水宏, 原田敬之, 他: 慶大皮膚科に扮け る過去 22 年間の皮虐悪性腫瘍の統計. 日皮会誌, 103:1743-1746, 1993.

8）上田英一郎, 岸本三郎, 安野洋一: 京都府立大学 皮虐科における最近 10 年間の皮虐悪性腫瘍の統 計的観察. 臨皮, 50:961-966, 1996.

9) Tada, M., Miki, Y.: Malignant skin tumors among dermatology patients in university hospitals of Japan ; J. Dermatol. 11 : 313-321, 1984.

10）清水善德, 安部誠, 増谷衛, 他 : 若年者に発生し た基底細胞上皮腫の 1 例. 皮虐臨床, 35:533-536, 1993.

11）勝海薰，島田稚，島垣和花，他：1976 年から 1990 年までの 15 年間の新潟大学皮膚科における悪性 黒色腫症例の統計的考察. Skin Cancer, 8:93-97, 1993.

12）梅林芳弘，大塚藤男：筑波大学皮虐科に扮ける悪 性黒色腫の統計的観察ならびに予後に関する検 討. Skin Cancer, 8: 55-61, 1993.

13）内田寛：最近 20 年間に扮ける悪性黒色腫教室例 の臨床的，統計的観察. 西日皮䖉，46 (増) : 129$135,1984$.

14）小山田亮, 神谷秀喜, 北島康雄：岐阜大学皮虐科 における Paget 病 47 例の統計的考察ならびに治 療と予後についての検討。西日皮虐，57：10531058, 1995.

15）大原國章, 大西泰彦, 川端康浩：乳房外 Paget 病 の診断と治療. Skin Cancer, 8 (special issue): 187208, 1993.

16）池田重雄，濱松輝美：腫瘍. 診断と治療，49： 2124-2131, 1974.

17) Brownstein, M. H., Helwig, E. B. : Patterns of cutaneous metastasis. Arch Dermatol, $105: 862-$ 868, 1972.

18）福井佳子, 徐信夫, 前島精治, 他：転移性皮虐癌 32 症例の統計学的観察. 皮膚, 37:534-543, 1995.

19）龍崎圭一郎, 田村敦志, 永井弥生, 他: 群馬大学 皮虐科に抒ける転移性皮虐癌の臨床的検討. 臨 皮, 51:500-503, 1997 . 